\title{
Michelangelo, mammillary bodies and the Creator
}

\author{
Michelangelo, corpos mamilares e o Criador \\ Péricles Maranhão-Filho ${ }^{1,2}$, Maurice B Vincent ${ }^{1}$
}

Michelangelo (1475-1564), a renaissance genius, left on the ceiling of the Sistine Chapel a superb work. Scholars consider this fresco, full of biblical figures, a great puzzle where the artist hid numerous anatomical parts. Two Brazilian authors $^{1}$ described neuropareidolically ${ }^{2}$ details of putative interpretations of these paintings where they envisioned dozens of organs, bones, joints, and a number of other aspects of the human anatomy. Regardless its veracity one of these illations is remarkably curious. The Creator is seen floating over the earth conceiving trees and plants. According to the authors, his gluteous represent the mammillary bodies (Figure).
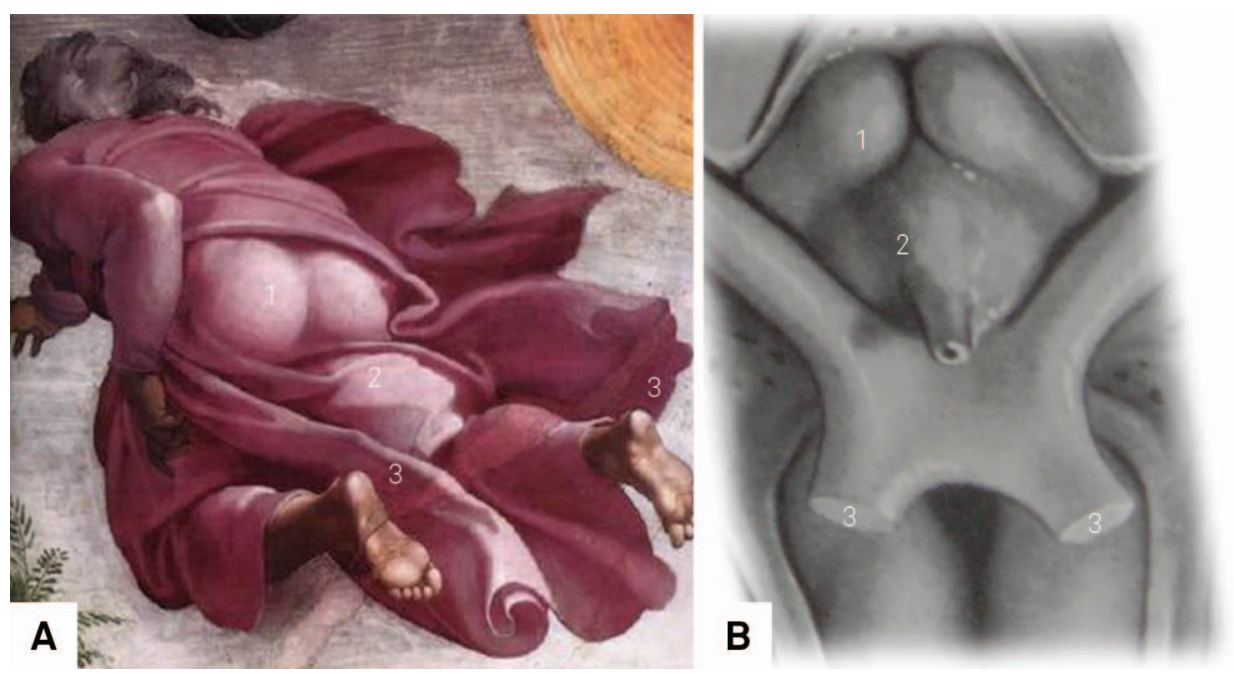

Figure. Detail of Michelangelo fresco (1511): "Creation of the sun, moon and plants". (A) 1. Buttocks; 2. Rounded volume; 3. Heels (Available at: http://www.artbible.info/art/large/663.html). (B) 1. Mammillary bodies; 2. Tuber cinereum with infundibulum of the pituitary gland; 3. Optic nerves (G. Wolf-Heidegger's Atlas of Systematic Human Anatomy Hafner Publishing Company Inc., New York, 1962).

\section{References}
1. Barreto G, Oliveira MG. Uma lição de anatomia na Capela Sistina. São Paulo: ARX; 2004. p. 78-9.

2.

Maranhão Filho P, Vincent MB. Neuropareidolia diagnostic clues apropos of visual illusions. Arq Neuropsiquiatr. 2009;67(4):1117-23. http://dx.doi.org/10.1590/S0004-282X2009000600033

\footnotetext{
${ }^{1}$ Universidade Federal do Rio de Janeiro, Hospital Universitário Clementino Fraga Filho, Rio de Janeiro RJ, Brazil; ${ }^{2}$ Instituto Nacional de Câncer, Rio de Janeiro RJ, Brazil.

Correspondence: Péricles Maranhão-Filho; Av Prefeito Dulcidio Cardoso, 1680 / 1802; 22620-311 Rio de Janeiro RJ, Brasil; E-mail: pmaranhaofilho@gmail. com

Conflict of interest: There is no conflict of interest to declare.

Received 22 September 2014; Received in final form 03 October 2014; Accepted 23 October 2014.
} 